\title{
PERSEPSI PEMILIH TERHADAP DESAIN MEDIA LUAR RUANG SALURAN KOMUNIKASI POLITIK PADA PILKADA 2020 DI RIAU
}

\author{
Muhammad Badri \\ Universitas Islam Negeri Sultan Syarif Kasim Riau \\ *Correspondence author: Muhammad Badri, muhammad.badri@uin-suska.ac.id, Pekanbaru, Indonesia
}

\begin{abstract}
Abstrak. Media luar ruang merupakan saluran komunikasi politik yang umum digunakan di Indonesia, termasuk pemilihan kepala daerah (Pilkada). Penelitian ini bertujuan untuk mengetahui persepsi pemilih terhadap media luar ruang yang digunakan untuk branding calon kepala daerah pada Pilkada 2020 di Riau. Penelitian ini menggunakan pendekatan kuantitatif dengan metode survei terhadap 225 pemilih di Riau. Studi ini menemukan bahwa hasil terpaan media luar ruang yang memuat iklan politik calon kepala daerah masih tinggi, dengan skor tertinggi adalah baliho, disusul spanduk dan poster. Berdasarkan perbandingan persepsi konsep desain, gambar, warna, tipografi, dan kreativitas pesan diperoleh data bahwa reklame lebih baik dalam konsep desain, penyajian warna, dan penggunaan tipografi. Sedangkan gambar yang ditampilkan di spanduk dinilai lebih baik. Dalam aspek kreativitas, pesan baliho dan poster dinilai lebih baik dari pada spanduk. Pada aspek pengaruh desain media luar ruang terhadap penggunaan hak pilih, pengaruh terbesar diberikan oleh poster dan paling sedikit spanduk meskipun perbedaannya tidak terlalu signifikan. Secara umum temuan penelitian ini menunjukkan fenomena bahwa media luar ruang masih efektif sebagai saluran komunikasi politik, meskipun media digital dan saluran komunikasi politik berbasis media sosial juga banyak digunakan.
\end{abstract}

Kata kunci: komunikasi politik, media luar ruang, desain grafis, pemilihan kepala daerah

\begin{abstract}
Outdoor media is a political communication channel commonly used in Indonesia, including regional head elections (called Pilkada). This study aims to determine voters' perceptions of outdoor media used for branding regional head candidates in the 2020 Pilkada in Riau. This study uses a quantitative approach with a survey method of 225 voters in Riau. This study found that outdoor media exposure which contains political advertisements for regional head candidates are still high, where the highest scores are billboards, followed by banners and posters. Based on the comparison of perceptions of design concepts, images, colors, typography, and message creativity, it is obtained data that billboards are better in design concepts, color presentation, and use of typography. Meanwhile, the image displayed in the banner is considered better. In the aspect of creativity, the messages of billboards and posters are considered better than banners. In the aspect of the influence of outdoor media design on the use of voting rights, the greatest influence is given by posters and the least banners although the difference is not too significant. In general, the findings of this study indicate the phenomenon that outdoor media is still effective as a political communication channel, although digital media and social media-based political communication channels are also widely used.
\end{abstract}

Keywords: political communication, outdoor media, graphic design, regional head elections 


\section{Pendahuluan}

Pemilihan Kepala Daerah (Pilkada) langsung merupakan agenda politik lima tahunan yang rutin digelar di Indonesia pasca reformasi. Pilkada dilakukan untuk memilih gubernur, bupati, dan walikota. Pilkada dengan sistem pemilihan langsung mendorong kandidat untuk berlombalomba membangun citra kepada pemilih. Pencitraan lazim dilakukan karena tidak semua pemilih mengenal sosok kandidat secara personal. Salah satu cara yang lazim dilakukan untuk membangun citra calon kepala daerah yaitu melalui media luar ruang. Hal ini tidak lepas dari filosofi dasar pencitraan yang berkaitan dengan kesadaran brand (brand awareness), dalam hal ini calon kepala daerah.

Media luar ruang masih dianggap efektif karena mudah dipasang di lokasi-lokasi strategis, menjangkau lebih banyak khalayak, dan bisa diakses tanpa bantuan perangkat elektronik maupun internet. Studi Nielsen Consumer Media \& View di 11 kota di Indonesia menemukan masih besarnya potensi penggunaan media luar ruang karena jangkauannya mencapai $66 \%$. Media luar ruang statis memiliki jangkauan tertinggi karena rata-rata dilihat 10 kali dalam seminggu (Nielsen 2019). Riset tentang media iklan Pilkada yang populer pada kalangan pemilih pemula juga menemukan bahwa para pemilih pemula lebih banyak mendapat informasi dari media cetak luar ruang dibanding media sosial, internet, media elektronik, dan media cetak (kumparan 2018). Kemudahan penggunaan media luar ruang menjadikan saluran tradisional komunikasi politik ini tetap digunakan pada Pilkada 2020.

Banyak alasan mengapa media luar ruang masih menjadi saluran komunikasi politik andal di tengah pesatnya inovasi saluran komunikasi digital. Salah satu yang penting dan utama adalah kemampuan menciptakan identitas dan daya tarik visual. Identitas visual diperlukan untuk menciptakan sebuah citra yang mudah dikenal khalayak (Ramadeni and Soewardikoen 2017), hal ini juga berlaku dalam kampanye atau promosi politik. Sebab, identitas visual bisa berarti merek bagi politisi. Studi menjelaskan bahwa simbol visual berpengaruh terhadap kesadaran merek (Prawita, Swasty, and Aditia 2017). Simbol-simbol visual banyak digunakan untuk personal branding politisi dalam Pilkada. Para politisi sadar karena personal branding dapat memberikan pengaruh terhadap perilaku pemilih (M. Harifin 2013). Personal branding merupakan strategi yang sangat efektif dan merupakan keharusan dalam sistem one man one vote dalam pemilihan kepala daerah (Haroen 2014).

Simbol visual telah lama menjadi komponen sentral komunikasi politik. Citra visual

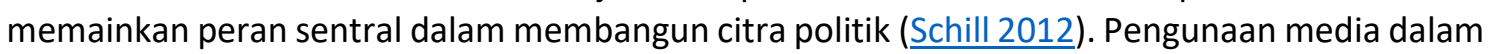
komunikasi politik berkaitan erat dengan konsep brand yaitu alat yang ampuh untuk membangun citra politik. Strategi branding bisa menjadi konsep sangat produktif untuk pemasaran politik. Citra merek diperebutkan di dunia yang lebih luas; rentan terhadap representasi media; dan dibentuk oleh preferensi warga, pengalaman, penggunaan media sehari-hari, dan percakapan antarpribadi (Scammell 2015). Pencitraan brand mungkin lebih relevan dalam kaitannya dengan kandidat individu, yang dapat mengembangkan reputasi lokal agar dapat diakses oleh konstituen (Needham and Smith 2015). Ketepatan dalam pemilihan media akan menentukan efektivitas pesan politik yang disampaikan calon kepala daerah dalam Pilkada (Asri, Arianti, and Mandjusri 2019).

Media luar ruang yang sering digunakan untuk kampanye politik yaitu baliho, spanduk, dan poster. Penelitian sebelumnya menemukan, politisi biasanya memasang foto yang cukup besar di media luar ruang, disertai pencitraan diri melalui slogan yang bernada patriotik, jargonis maupun idealis baik secara verbal maupun nonverbal (Purnengsih 2017). Elemen visual yang dipilih dalam media luar ruang umumnya memiliki pola sama, yaitu menampilkan foto bakal calon dalam ukuran besar. Tujuannya agar khalayak dapat mengingat wajah bakal calon sehingga pada saat Pilkada dapat menentukan pilihan (Darmawan 2018). Meski demikian, 
penggunaan media luar ruang yang terlalu banyak dianggap mengganggu keindahan, mengotori lingkungan, merusak pemandangan kota, dan akan menghasilkan lebih banyak sampah (Yuliyanto 2016; Andu and Hardiyanti 2019).

Riset sebelumnya lebih banyak mengungkap penggunaan media luar ruang untuk komunikasi politik dari sudut pandang pencitraan, kajian elemen visual, dan dampaknya bagi lingkungan. Belum banyak riset yang menganalisis persepsi khalayak terhadap elemen desain media luar ruang, sehingga kajian dari perspektif masyarakat menarik dilakukan. Salah satu daerah yang menggelar Pilkada pada tahun 2020 dan menarik diteliti adalah Provinsi Riau. Di provinsi ini terdapat sembilan daerah yang mengadakan pemilihan bupati dan walikota dan para calon kepala daerah banyak menggunakan media luar ruang untuk kampanye di tengah pandemi Covid-19 yang membatasi kerumunan massa.

Penelitian ini bertujuan untuk mengetahui persepsi pemilih terhadap media luar ruang yang digunakan untuk kampanye politik pada Pilkada 2020 di Provinsi Riau. Persepsi merupakan proses seseorang memiliki kesadaran tentang objek dan peristiwa terutama yang dapat dirasakan panca indra. Persepsi penting dalam komunikasi karena akan memengaruhi pilihan komunikasi (DeVito 2017). Proses persepsi dipengaruhi oleh faktor internal (kepercayaan, pengalaman, kebutuhan, suasana hati, dan harapan) dan karakteristik stimulus (ukuran, warna, dan intensitas) serta konteks di mana stimulus itu diperoleh (Morissan 2010). Menurut hukum dasar persepsi visual, pola stimulus apapun cenderung dilihat sedemikian rupa sehingga struktur yang dihasilkan sesederhana kondisi yang diizinkan (Arnheim 2011).

Dalam artikel ini, persepsi dimaksudkan sebagai tanggapan responden terhadap objek media luar ruang sebagai saluran komunikasi politik calon kepala daerah pada Pilkada 2020 di Provinsi Riau. Berdasarkan observasi, terdapat tiga jenis media luar ruang yang banyak digunakan untuk komunikasi politik yaitu baliho, spanduk, dan poster. Penelitian ini mengeksplorasi persepsi responden terhadap tiga jenis media tersebut dengan indikator terpaan media, konsep desain, gambar/ ilustrasi, warna, tipografi, kreativitas pesan, dan pengaruh desain terhadap penggunaan hak pilih.

\section{Metode}

Penelitian ini menggunakan pendekatan kuantitatif dengan metode survei. Dalam rancangan survei, peneliti mendeksripsikan secara kuantitatif kecenderungan, perilaku, atau opini dari suatu populasi (Creswell 2016). Pengumpulan data dilakukan melalui penyebaran angket kepada 225 responden yang memiliki hak pilih pada Pilkada 2020 di Riau. Responden penelitian ini terdiri atas 129 laki-laki (57.3\%) dan 96 perempuan (42.7\%). Sebagian besar responden merupakan kelompok masyarakat yang sedang dan pernah mengikuti pendidikan tinggi (66.2\%) diikuti SMA (26.7\%) dan selebihnya tamatan SMP (3.1\%) dan SD (4\%).

Instrumen penelitian mencakup terpaan media dan persepsi terhadap desain tiga jenis media luar ruang yang lazim digunakan pada kampanye Pilkada yaitu baliho, spanduk, dan poster. Indikator yang diteliti meliputi terpaan media luar ruang, penilaian terhadap konsep desain, gambar, warna, tipografi, kreativitas pesan, dan pengaruh desain terhadap penggunaan hak pilih. Data yang dikumpulkan kemudian dianalisis secara deskriptif untuk disajikan dalam bentuk distribusi frekusensi lalu dibandingkan menggunakan formula Weight Means Score (WMS). 


\section{Hasil dan Pembahasan}

\section{Persepsi terhadap Desain Baliho}

Baliho merupakan media promosi luar ruang yang memiliki ukuran cukup besar. Baliho sering digunakan untuk menyampaikan pesan, promosi, iklan, dan berbagai pemberitahuan kepada masyarakat umum (swastika 2019). Media tersebut hingga saat ini masih digunakan sebagai media iklan utama karena berdimensi sangat besar sehingga bisa dilihat banyak orang (Haryadi and Saputro 2018). Baliho biasanya terpampang di jalan raya dengan lalu lintas ramai (Surya, Prasetyo, and Witasari 2017).

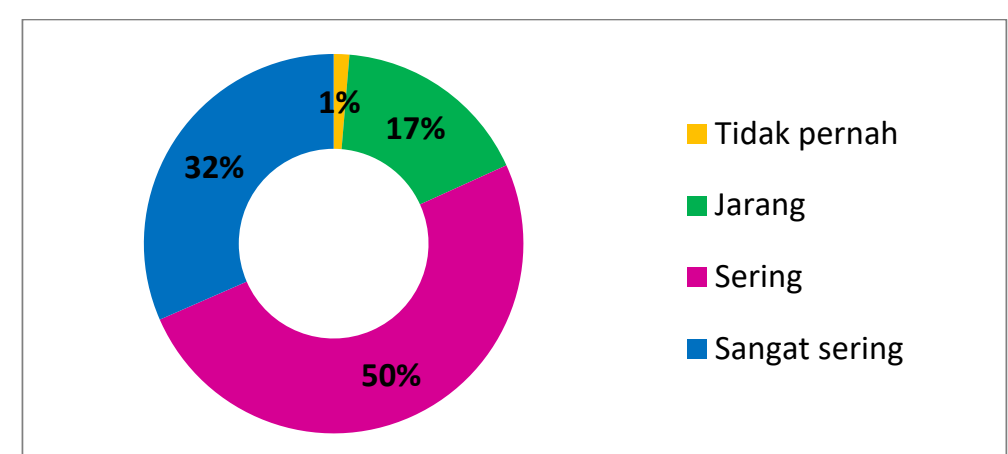

Gambar 1. Terpaan responden terhadap baliho Pilkada 2020 di Riau

Penelitian ini menemukan sebagian besar responden sering (50\%) melihat baliho calon kepala daerah pada Pilkada 2020 di Riau (Gambar 1). Baliho umumnya dipasang di lokasi dengan lalu lintas ramai seperti pusat pemerintahan, pusat perekonomian, pusat kegiatan sosial, dan persimpangan jalan. Selanjutnya, Gambar 2 menjelaskan bahwa sebagian besar responden menyatakan konsep desain baliho yang dibuat oleh calon kepala daerah pada Pilkada 2020 di Riau menarik (72.1\%). Responden juga menyatakan kualitas gambar yang ditampilkan dalam desain baliho bagus (75.7\%).

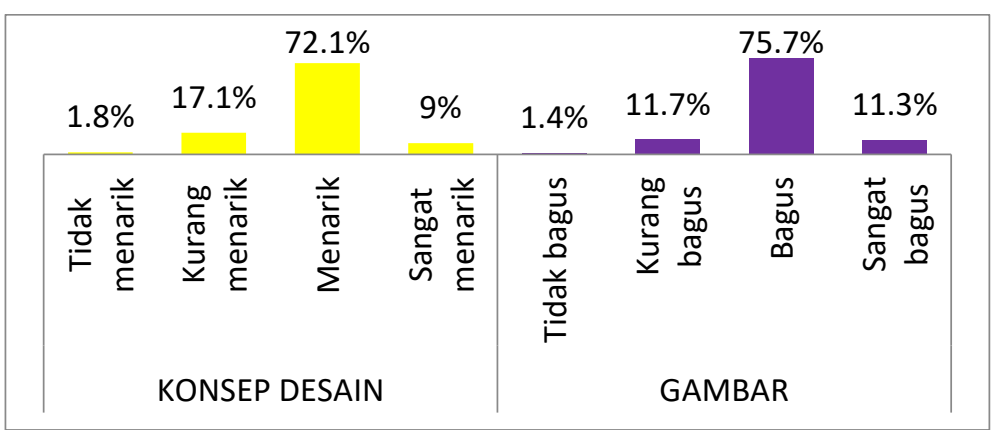

Gambar 2. Persepsi responden terhadap konsep desain dan gambar baliho Pilkada 2020

Gambar 3 menjelaskan sebagian besar responden menilai warna yang ditampilkan pada baliho Pilkada 2020 di Riau terlihat dengan jelas (73.9\%). Kemudian tipografi yang digunakan dalam desain baliho juga mudah dibaca $(79.3 \%)$. 


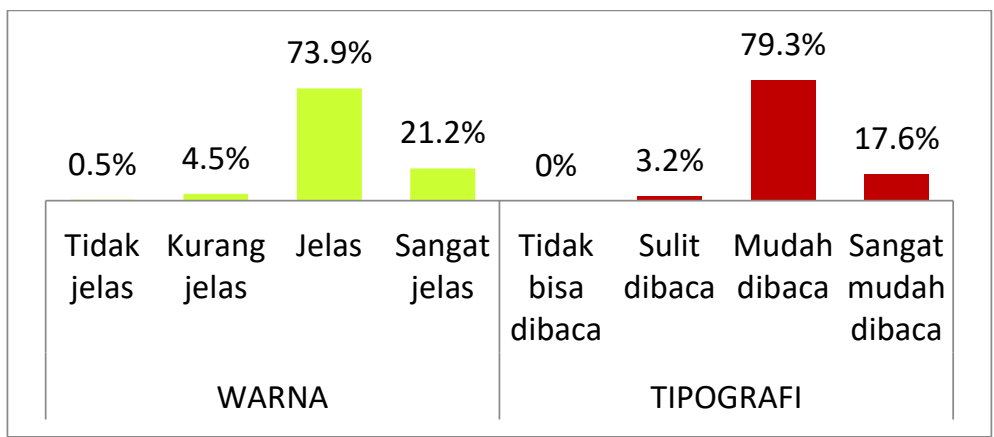

Gambar 3. Persepsi responden terhadap warna dan tipografi baliho Pilkada 2020

Gambar 4 menjelaskan sebagian besar responden menyatakan desain pesan baliho Pilkada 2020 di Riau kreatif (65.8\%). Menurut $44.1 \%$ responden, desain baliho yang dibuat oleh calon kepala daerah dapat mempengaruhi mereka untuk memberikan pilihan.

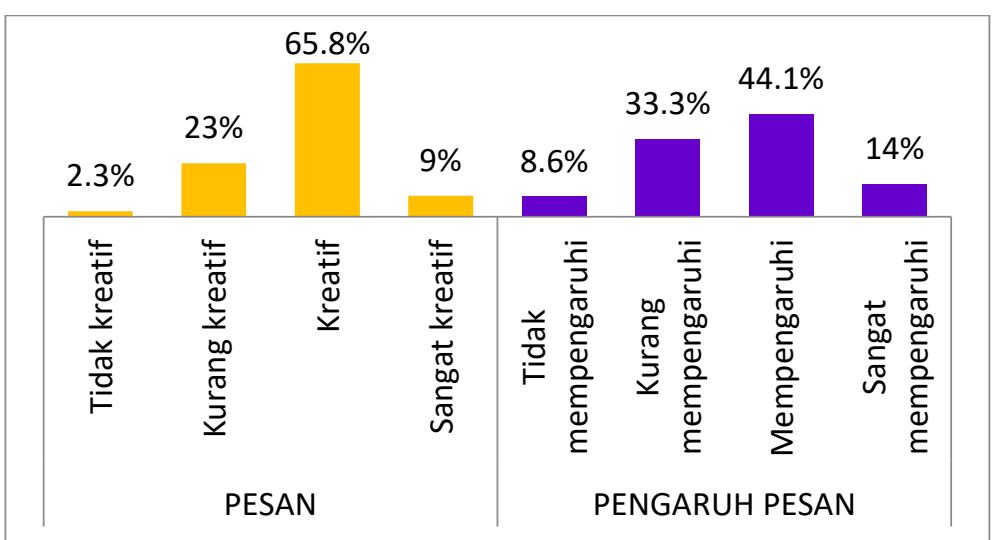

Gambar 4. Persepsi responden terhadap kreativitas pesan baliho Pilkada dan pengaruhnya terhadap pemberian hak pilih

\section{Persepsi terhadap Desain Spanduk}

Spanduk merupakan kain atau media lain yang direntangkan, berisi rangkaian gambar dan tulisan dan dipasang di tepi jalan dengan tujuan menarik minat khalayak (Rahman, Utami, and Raden 2018). Spanduk juga digunakan partai politik untuk mempromosikan visi, misi, dan slogan guna menggalang dukungan, termasuk pada masa kampanye Pemilu dan Pilkada (HS 2008; Ahmad 2011). Dalam Pilkada spanduk digunakan untuk pengingat masyarakat terhadap citra kandidat (Aprillia and Baitullah 2019).

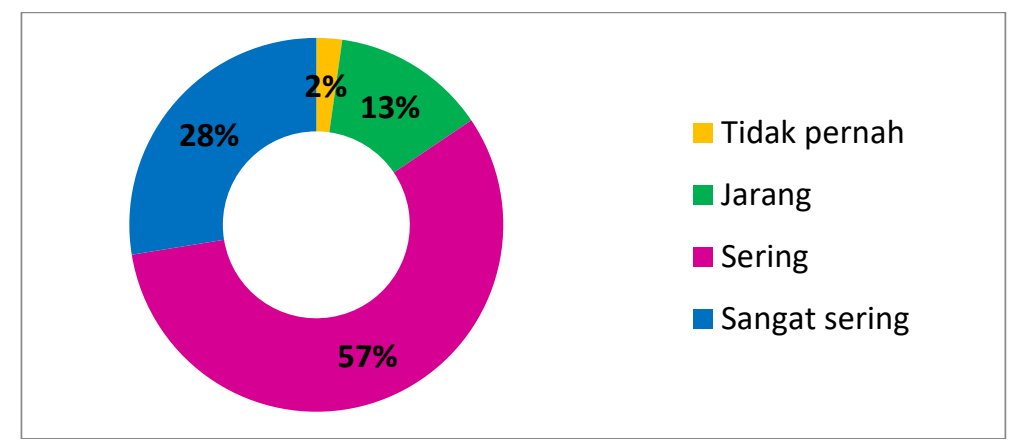

Gambar 5. Terpaan responden terhadap spanduk Pilkada 2020 di Riau 
Penelitian ini menemukan sebagian besar responden sering $(57 \%)$ melihat spanduk calon kepala daerah pada Pilkada 2020 di Riau (Gambar 5). Berbeda dengan baliho, selain dipasang di lokasi berlalu lintas ramai spanduk juga dibentangkan di kawasan permukiman.

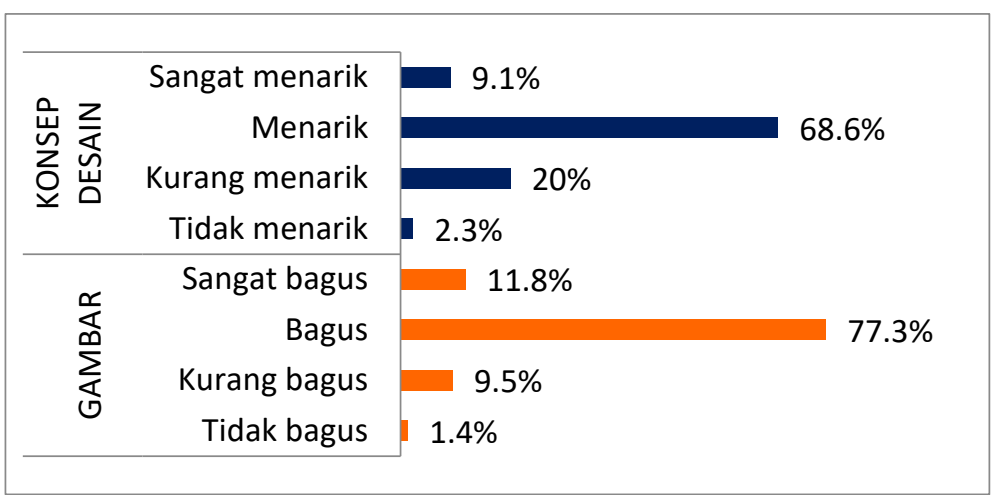

Gambar 6. Persepsi responden terhadap konsep desain dan gambar spanduk Pilkada 2020

Gambar 6 menjelaskan sebagian besar responden menyatakan konsep desain spanduk calon kepala daerah pada Pilkada 2020 di Riau menarik (68.6\%). Responden juga menilai gambar yang ditampilkan dalam spanduk bagus (77.3\%).

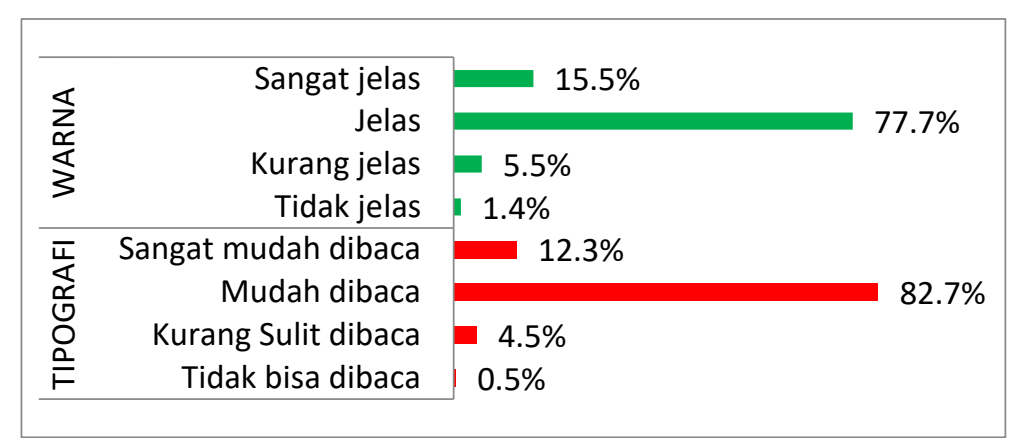

Gambar 7. Persepsi responden terhadap warna dan tipografi spanduk Pilkada 2020

Gambar 7 menjelaskan sebagian besar responden menilai warna yang ditampilkan dalam spanduk Pilkada 2020 di Riau jelas (77.7\%). Responden juga menilai tipografi yang digunakan mudah dibaca (82.7\%). Selanjutnya, Gambar 8 menjelaskan sebagian besar responden menyatakan desain pesan spanduk Pilkada 2020 di Riau kreatif (67.3\%) dan 49.1\% responden menyatakan mempengaruhi mereka untuk memilih.

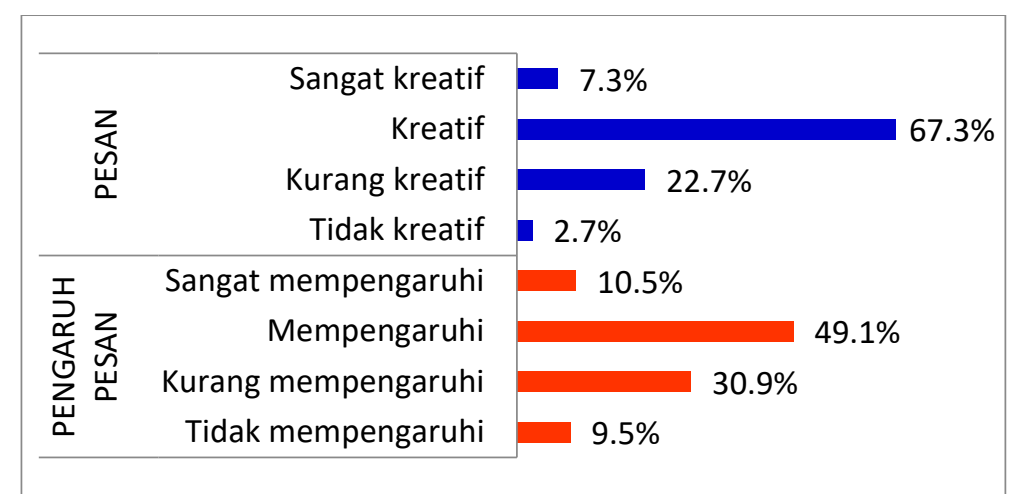

Gambar 8. Persepsi responden terhadap kreativitas pesan spanduk Pilkada dan pengaruhnya terhadap pemberian hak pilih 


\section{Persepsi terhadap Desain Poster}

Poster merupakan karya desain grafis berisi gambar dan huruf yang biasanya menggunakan warna-warna kuat dan mencolok, kemudian diaplikasikan di kertas dan ditempel di permukaan datar (swastika 2019). Poster sebagai media penarik perhatian merupakan alat yang efektif untuk kegiatan promosi (Bramantha 2017). Unsur-unsur keindahan, komunikasi, dan daya gugah menjadi pertimbangan dalam menyampaikan pesan melalui poster kepada masyarakat (Setianto 2016).

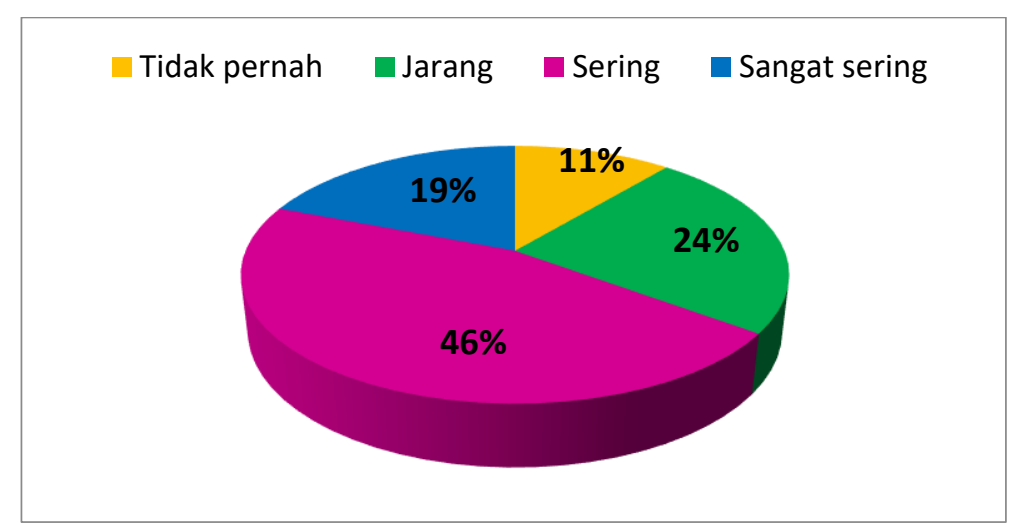

Gambar 9. Terpaan responden terhadap poster Pilkada 2020 di Riau

Penelitian ini menemukan sebagian besar responden sering (57\%) melihat poster calon kepala daerah pada Pilkada 2020 di Riau (Gambar 9). Poster biasanya dipasang di ruang publik yang memiliki bidang datar. Sampai sekarang poster konvensional masih sering digunakan untuk menyampaikan pesan, terutama dalam periklanan, baik itu iklan produk, jasa, maupun kegiatan (Abdillah, Maeni, and Nurmalinda 2020). Poster konvensional masih memiliki daya tarik, padahal banyak poster digital yang disebarkan melalui media sosial seperti Facebook, Instagram, dan Twitter (Muntazori 2020). Masih tingginya minat khalayak terhadap poster konvensional menyebabkan calon kepala daerah juga menggunakan poster untuk komunikasi politik.

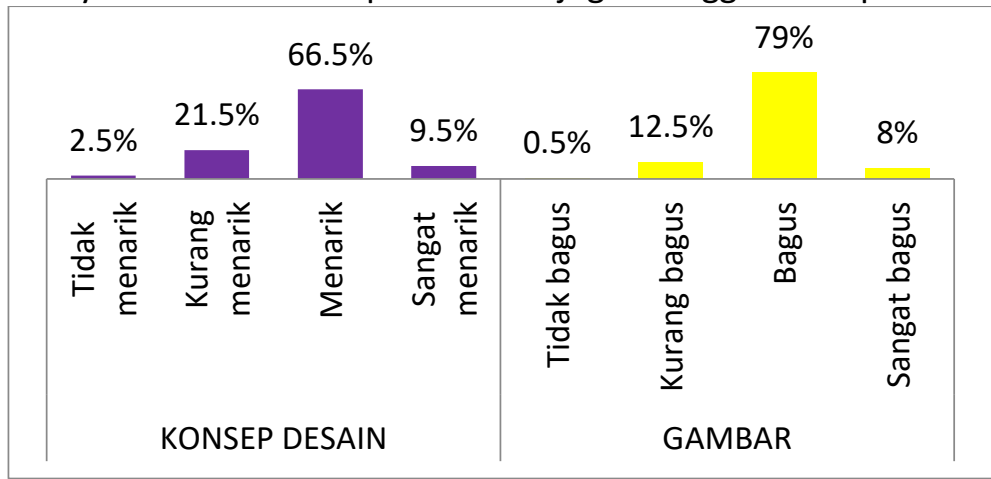

Gambar 10. Persepsi responden terhadap konsep desain dan gambar poster Pilkada 2020

Gambar 10 menjelaskan sebagian besar responden menyatakan konsep desain poster calon kepala daerah pada Pilkada 2020 di Riau menarik (66.5\%). Sebagian besar juga responden menilai gambar yang ditampilkan dalam poster bagus (79\%). 


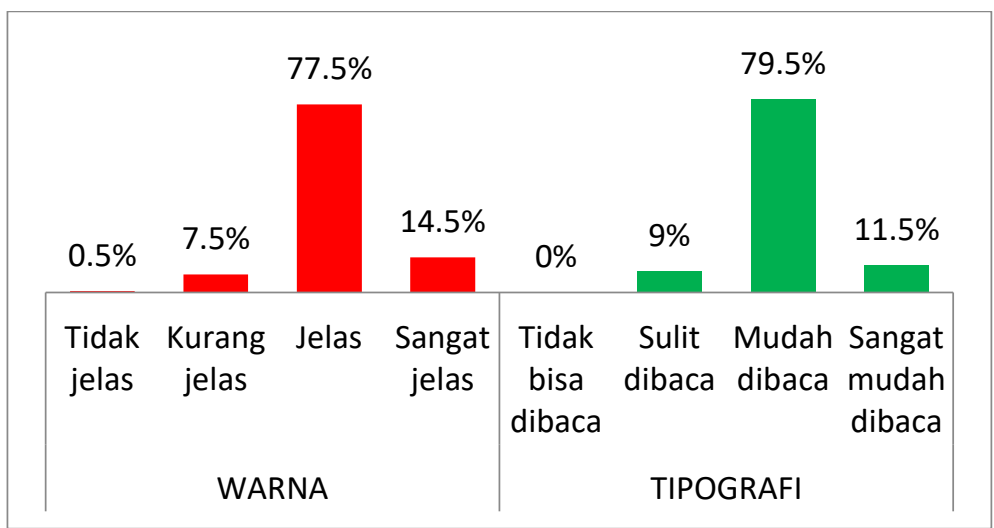

Gambar 11. Persepsi responden terhadap warna dan tipografi spanduk Pilkada

Gambar 11 menunjukkan bahwa sebagian besar responden menilai warna yang ditampilkan dalam poster calon kepala daerah pada Pilkada 2020 di Riau jelas (77.5\%) dan tipografi yang digunakan mudah dibaca (79.5\%). Selanjutnya Gambar 12 menjelaskan sebagian besar responden menilai desain pesan poster Pilkada kreatif (68\%) dan $45 \%$ menyatakan mempengaruhi mereka untuk memilih.

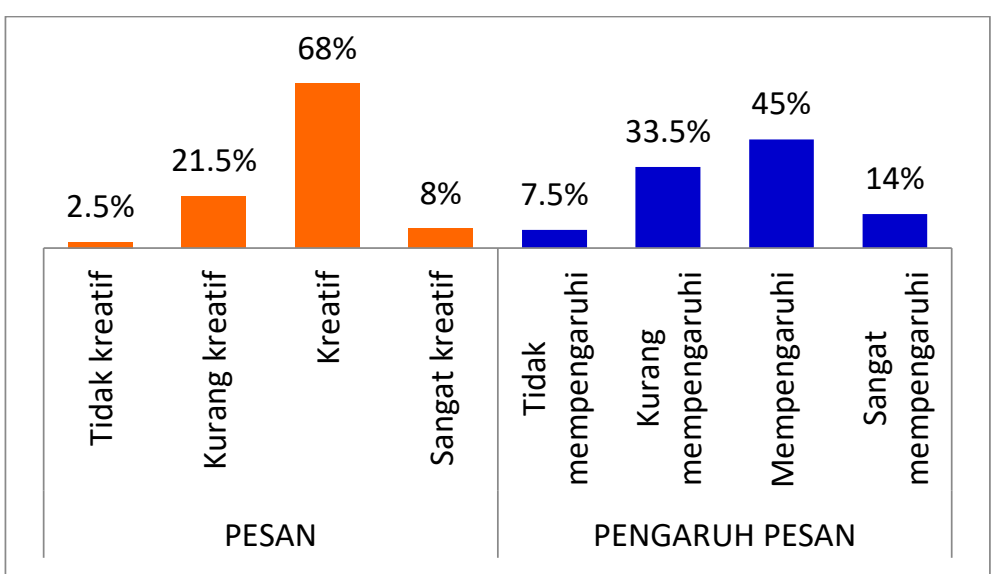

Gambar 12. Persepsi responden terhadap kreativitas pesan poster Pilkada dan pengaruhnya terhadap pemberian hak pilih

\section{Pembahasan}

Media luar ruang sampai saat ini masih digunakan sebagai saluran komunikasi politik, termasuk Pilkada. Calon kepala daerah bisa mengandalkan media luar ruang untuk menjangkau khalayak luas dan menjangkau berbagi kelompok usia, jenjang pendidikan, gender, dan berbagai profil sosial ekonomi lainnya. Media luar ruang juga mampu menjangkau semua wilayah baik perkotaan maupun perdesaan, bahkan dapat digunakan untuk komunikasi politik di wilayah yang tidak terjangkau jaringan listrik dan internet. Keunggulan relatif media luar ruang menjadikan media ini tetap populer di tengah maraknya penggunaan media sosial untuk komunikasi politik.

Di era digital media luar ruang masih mendominasi iklan politik dalam Pilkada karena muncul hampir di setiap ruas jalan seperti tikungan, tanjakan, tiang listrik, tembok, hingga pepohonan (kumparan 2018). Meskipun informasi yang disajikan di dalam media luar ruang singkat dan tidak lengkap, seperti tidak menjelaskan siapa calon dan program kerja yang ditawarkannya, namun dinilai mampu mengenalkan calon kepada masyarakat karena frekuensi seringnya terlihat di jalan yang dilewati (Darmawan 2018). Di semua daerah konsep desain media luar ruang sebagai iklan politik relatif sama, yaitu menampilkan informasi utama berupa 
foto bakal calon, jargon politik, logo partai pendukung, dominasi warna sesuai latar belakang politik calon atau partai pendukung.

Penelitian ini menemukan bahwa pemilih pada Pilkada Riau 2020 sering mendapat terpaan media luar ruang baliho, spanduk, dan poster yang berisi iklan politik calon kepala daerah. Responden menilai konsep desain baliho, spanduk, dan poster menarik. Gambar yang ditampilkan dalam desain baliho, spanduk, dan poster dinilai bagus, menggunakan warna yang jelas, dan tipografi yang mudah dibaca. Menurut responden pesan pada baliho, spanduk, dan poster dirancang dengan kreatif. Terpaan dan persepsi terhadap unsur-unsur desain ketiga media luar ruang tersebut kemudian mempengaruhi responden untuk memberikan hak pilih.

Untuk mendapatkan perbandingan persepsi antara baliho, spanduk, dan poster, penulis menggunakan rumus Weight Means Score (WMS) dengan indikator: 1\% sampai 20\% (sangat rendah), 21\% sampai 40\% (rendah), 41\% sampai 60\% (Sedang), 61\% sampai 80\% (tinggi), dan $81 \%$ sampai $100 \%$ (sangat tinggi). Pada indikator terpaan media luar ruang ketiga media mendapat skor tinggi, di mana skor terpaan paling tinggi yaitu baliho (78\%), diikuti spanduk (77.4\%), dan poster (68.2\%). Temuan ini menunjukkan baliho yang memiliki ukuran cukup besar dan biasanya dipasang di lokasi-lokasi strategis dengan lalu lintas ramai seperti pusat pemerintahan, pusat perekonomian, pusat kegiatan sosial, dan persimpangan jalan mendapat perhatian khalayak paling tinggi (Gambar 13). Penelitian sebelumnya juga menyebutkan ukurannya yang besar dan mudah dilihat orang menjadikan baliho masih digunakan sebagai media iklan utama (Haryadi and Saputro 2018).

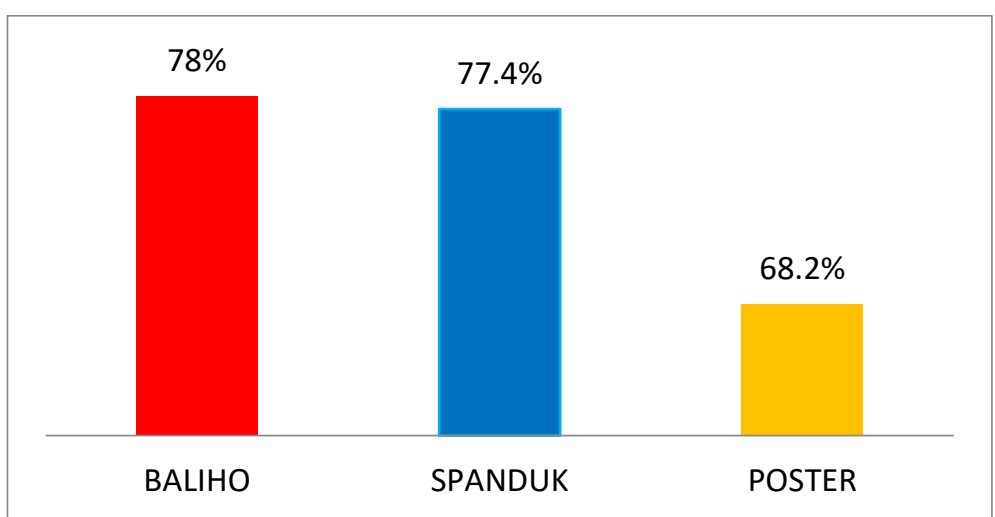

Gambar 13. Perbandingan terpaan media luar ruang Pilkada 2020 di Riau

Selanjutnya, berdasarkan perhitungan perbandingan persepsi terhadap terhadap konsep desain, gambar, warna, tipografi, dan kreativitas pesan, diperoleh data bahwa baliho lebih baik dalam konsep desain, penyajian warna, dan penggunaan tipografi. Sementara itu menurut penilaian responden gambar yang ditampilkan dalam spanduk lebih bagus. Pada aspek kreativitas pesan baliho dan poster dinilai lebih baik dibandingkan kreativitas pesan dalam desain spanduk. Secara keseluruhan persepsi reponden terhadap unsur-unsur desain baliho, spanduk, dan poster berada dalam rentang skor tinggi (60\%-80\%) yang dapat dikonversikan dengan "baik" atau "efektif" (Gambar 14). Hal ini menunjukkan persepsi responden terhadap ketiga jenis media ini relatif baik. Artinya media luar ruang masih dianggap sebagai media yang efektif sebagai sumber informasi untuk membentuk citra calon kepala daerah. 


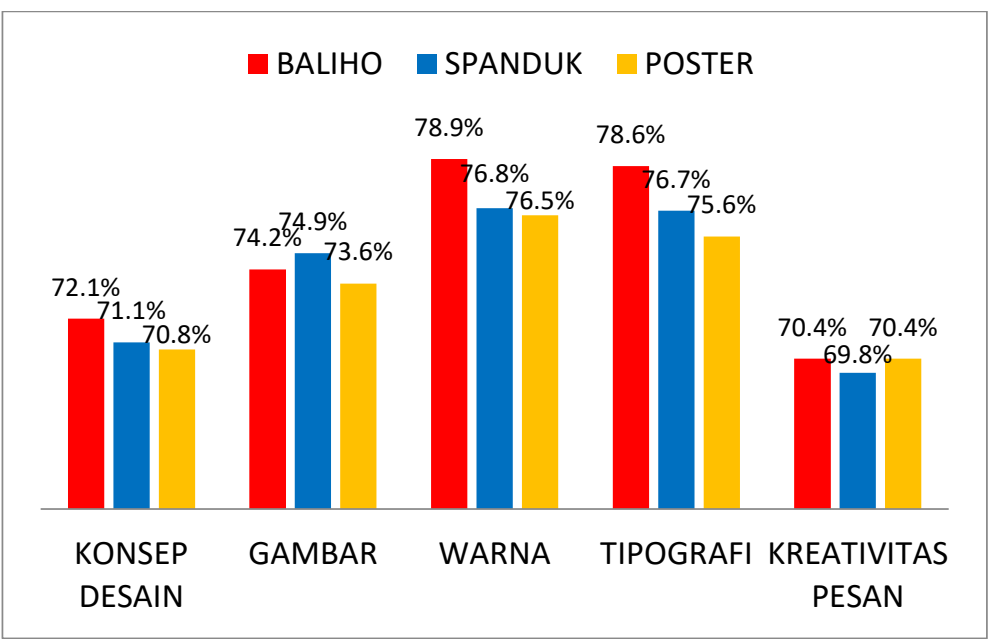

Gambar 14. Perbandingan persepsi baliho, spanduk, dan poster pada Pilkada 2020 di Riau

Pada aspek pengaruh desain media luar ruang terhadap penggunaan hak pilih, penelitian ini menemukan bahwa pengaruh terbesar justru diberikan oleh poster (66.4\%) dan pengaruh paling sedikit spanduk (65.1\%) meskipun perbedaannya tidak terlalu signifikan (Gambar 15). Temuan ini menarik untuk diteliti lebih lanjut sebab terpaan poster lebih rendah dibanding baliho dan spanduk. Dalam konteks ini, penulis melihat khalayak sering memahami media luar ruang yang digunakan untuk kampanye politik selain baliho dan spanduk sebagai poster. Beberapa contoh desain media luar ruang yang menyerupai poster adalah kalender, sticker berukuran setara $\mathrm{A} 5$, pamflet, dan poster berbahan flexi (bahan cetak digital) yang sering dipasang di tiang listrik, dipajang di pinggir jalan, bahkan ada yang dipasang di pohon.

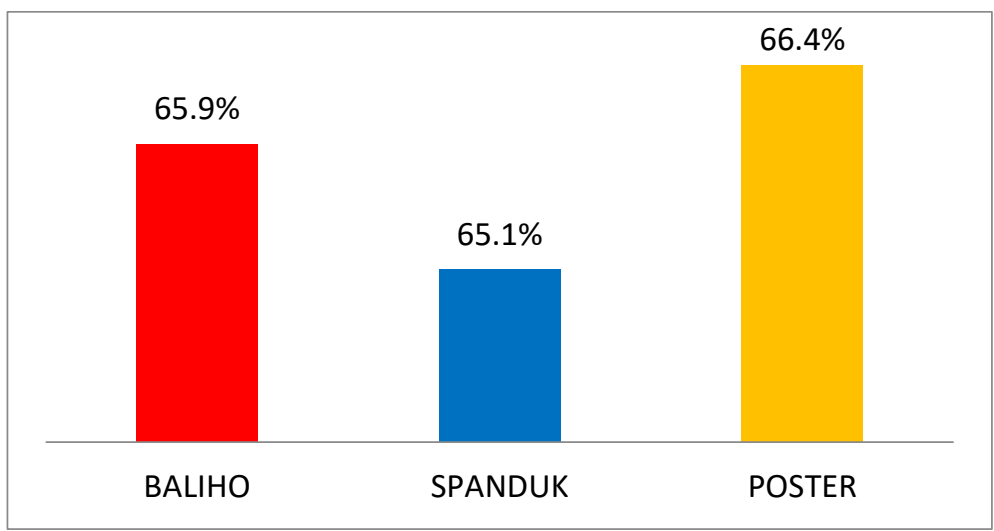

Gambar 15. Perbandingan pengaruh baliho, spanduk, dan poster pada Pilkada 2020 di Riau

Secara umum temuan penelitian ini menunjukkan suatu fenomena bahwa media luar ruang khususnya baliho, spanduk, dan poster masih efektif sebagai saluran komunikasi politik karena skor terpaan, persepsi terhadap unsur-unsur desain, dan pengaruhnya terhadap penggunaan hak pilih berada dalam rentang skor tinggi (60\%-80\%). Temuan ini sejalan dengan studi Nielsen Consumer Media \& View yang menjelaskan media luar ruang masih memiliki jangkauan hingga 66\% (Nielsen 2019) dan populer pada kalangan pemilih pemula (kumparan 2018). Terlepas apakah dipengaruhi media luar ruang atau faktor lain, Komisi Pemilihan Umum (KPU) Riau menjelaskan, tingkat partisipasi pemilih pada pemilihan 2020 di sembilan daerah di Riau rata-rata mencapai $70.39 \%$ atau meningkat 5.36\% dibanding Pilkada 2015 yakni $65.03 \%$ (Yunanda 2020). Meskipun citra visual yang disuguhkan media luar ruang memainkan peran

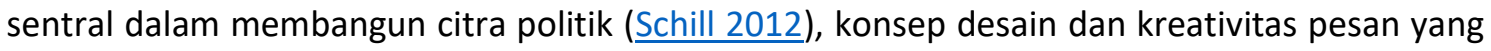


disampaikan perlu ditingkatkan karena rata-rata skornya masih lebih rendah dari persepsi terhadap gambar, warna, dan tipografi. Selain itu, sama seperti Yuliyanto (2016) dan Andu and Hardiyanti (2019) penggunaan media luar ruang sebaiknya juga memperhatikan estetika lingkungan dan tidak menghasilkan sampah yang menggangu masyarakat.

\section{Simpulan}

Media luar ruang merupakan saluran komunikasi politik yang masih populer digunakan pada Pilkada 2020 di Provinsi Riau. Calon kepala daerah umumnya menggunakan baliho, spanduk, dan poster untuk membangun personal branding dan mencitrakan dirinya sebagai sosok yang layak dipilih sebagai pasangan bupati/ walikota. Meskipun saluran komunikasi politik berbasis media digital dan media sosial juga banyak digunakan, ternyata terpaan media luar ruang masih tinggi. Masyarakat juga memiliki persepsi yang baik terhadap konsep desain, gambar, warna, tipografi, dan kreativitas pesan yang disampaikan oleh para calon kepala daerah. Hal tersebut kemudian memberikan pengaruh tinggi terhadap minat menggunakan hak pilih. Laporan KPU Riau juga menyebutkan bahwa meskipun pada situasi pandemi Covid-19 partisipasi pemilih pada Pilkada Riau 2020 masih tinggi bahkan meningkat dibanding Pilkada 2015. Penelitian ini memiliki keterbatasan belum menggali data kualitatif, sehingga diharapkan penelitian selanjutnya dapat menjelaskan dari sudut pandang kualitatif agar dapat memberikan gambaran yang lebih personal.

\section{Penghargaan}

Penulis mengucapkan terima kasih kepada mahasiswa kelas Desain Grafis Public Relations $2020 / 2021$ yang membantu proses pengumpulan data primer sebagai enumerator.

\section{Referensi}

Abdillah, Fadhly, Purmaningrum Maeni, and Erna Nurmalinda. 2020. "Analisis Narasi Visual Poster Asian Games 2018 Versi Panahan (Mel Ahyar)." Jurnal Desain 7 (2): 126-135. https://doi.org/10.30998/jd.v7i2.5832.

Ahmad, Irdam. 2011. "Spanduk dan Stiker sebagai Media Komunikasi untuk Melaporkan Peristiwa Kependudukan." Jurnal ilmu komunikasi 9 (1): 28-39. http://jurnal.upnyk.ac.id/index.php/komunikasi/article/view/3413.

Andu, Christine Purnamasari, and Sartika Dwi Hardiyanti. 2019. "Pengaruh Baliho Terhadap Pilihan Politik Masyarakat Kelas Menengah Pada Pilkada Di Kota Makassar." Jurnal $\begin{array}{llll}\text { Representamen } & 5 & \text { (02). http://jurnal.untag- }\end{array}$ sby.ac.id/index.php/representamen/article/view/2941.

Aprillia, Helsa, and Baitullah. 2019. "Persuasif Pada Spanduk Pilkadadi Kabupaten Merangin Tahun 2017-2018." Jurnal Tunas Pendidikan 2 (1): 82-91. http://ejournal.stkipmmb.ac.id/index.php/pgsd/article/view/196.

Arnheim, Rudolf. 2011. Art and Visual Perception: A Psychology of the Creative Eye. University of California Press. 
170 Persepsi Pemilih terhadap Desain Media Luar Ruang Saluran Komunikasi Politik pada Pilkada 2020 di Riau

Asri, Rahman, Gusmia Arianti, and Alma Mandjusri. 2019. "Pengaruh online personal branding tokoh politik terhadap minat pemilih pemula." Communiverse : Jurnal Ilmu Komunikasi 5 (1): 58-69. https://doi.org/10.36341/cmv.v5i1.1166.

Bramantha, Octavianus. 2017. "Kajian Struktur Poster'Hope'Barrack Obama." NARADA: Jurnal Desain Dan Seni 4 275-287. https://publikasi.mercubuana.ac.id/index.php/narada/article/view/3226.

Creswell, John W. 2016. RESEARCH DESIGN: Pendekatan Metode Kualitatif Kuantitatif Dan Campuran. Translated by Achmad Fawaid and Rinayanti Kusmini Pancasari. 4th ed. Yogyakarta: Pustaka Pelajar.

Darmawan, Ferry. 2018. "Modalitas Visual Komunikasi Politik Iklan Pilkada Kota Bandung 2018." Mediator: Jurnal Komunikasi 11 (1): https://doi.org/10.29313/mediator.v11i1.3155.

DeVito, Joseph A. 2017. Essentials of Human Communication. Ninth ed. Boston: Pearson.

Haroen, Dewi. 2014. Personal Branding: Kunci Kesuksesan Berkiprah Di Dunia Politik. Jakarta: Gramedia Pustaka Utama.

Haryadi, Toto, and Godham Eko Saputro. 2018. "Tinjauan Desain Iklan Dalam Sudut Pandang Majas Visual (Studi Kasus: Iklan Media Billboard di Kota Semarang)." Desain Komunikasi Visual, Manajemen Desain dan Periklanan (Demandia) 3 (1): 97-115. https://doi.org/10.25124/demandia.v3i1.1213.

//journals.telkomuniversity.ac.id/demandia/article/view/1213.

HS, Isbandiyah. 2008. "Wajah Spanduk Solidaritas Gempa Yogyakarta: Tinjauan Dari Perspektif Komunikasi." Jurnal IImu Sosial dan IImu Politik 11 (3): 331-356. https://jurnal.ugm.ac.id/jsp/article/view/10991.

kumparan. 2018. "Media Luar Ruang Masih Efektif Untuk Kampanye." Kumparan, 27 Juni, 2018. https://kumparan.com/bandungkiwari/media-luar-ruang-masih-efektif-untukkampanye/full.

M. Harifin, Kurniawati. 2013. "Pengaruh Personal Branding Dan Positioning Terhadap Perilaku Pemilih Dalam Pemilukada Di Kabupaten Bonebolango." Politika: Jurnal IImu Politik 3 (1): $\quad 18 . \quad$ https://doi.org/10.14710/politika.3.1.2012.15-32. https://ejournal.undip.ac.id/index.php/politika/article/view/4825.

Morissan. 2010. Periklanan Komunikasi Pemasaran Terpadu. Jakarta: Kencana.

Muntazori, Ahmad Faiz. 2020. "Dakwah Visual: Ekspresi Keimanan Seorang Muslim dalam Poster Digital." Human Narratives 1 (2): 88-102. https://doi.org/10.30998/hn.v1i2.351.

Needham, Catherine, and Gareth Smith. 2015. "Introduction: Political Branding." Journal of Political Marketing 14 (1-2): 1-6. https://doi.org/10.1080/15377857.2014.990828.

Nielsen. 2019. "Media Luar Ruang Sebagai Strategi Marketing." Nielsen Global Media. Last Modified 26 Juni. https://www.nielsen.com/id/id/press-releases/2019/media-luarruang-sebagai-strategi-marketing/. 
Prawita, Riztama, Wirania Swasty, and Patra Aditia. 2017. "Membangun Identitas Visual Untuk Media Promosi Usaha Mikro Kecil Dan Menengah." Jurnal Sosioteknologi 16 (1): 27-42. https://doi.org/10.5614/sostek.itbj.2017.16.1.3.

Purnengsih, lis. 2017. "Makna dan Pesan dalam Baliho Pemilu Legislatif 2014." Jurnal Desain 4 (03):

231-248.

https://journal.Ippmunindra.ac.id/index.php/Jurnal Desain/article/view/1604.

Rahman, Nadya Nur, Rahayu Sri Utami, and Agung Zainal Muttakin Raden. 2018. "Analisis Tipografi pada Spanduk Pemasaran Perumahan." Jurnal Desain 5 (03): 250-257. https://journal.Ippmunindra.ac.id/index.php/Jurnal Desain/article/view/2572.

Ramadeni, Sari, and Didit Widiatmoko Soewardikoen. 2017. "Identitas Visual Dan Media Promosi Wisata Edukasi Jendela Alam." Desain Komunikasi Visual, Manajemen Desain $\begin{array}{lllll}\text { dan } & \text { Periklanan } & \text { (Demandia) } & 2 & \text { (1): }\end{array}$ https://doi.org/10.25124/demandia.v2i01.767.

//journals.telkomuniversity.ac.id/demandia/article/view/767.

Scammell, Margaret. 2015. "Politics and Image: The Conceptual Value of Branding." Journal of Political Marketing 14 (1-2): 7-18. https://doi.org/10.1080/15377857.2014.990829.

Schill, Dan. 2012. "The Visual Image and the Political Image: A Review of Visual Communication Research in the Field of Political Communication." Review of Communication 12 (2): 118142. https://doi.org/10.1080/15358593.2011.653504.

Setianto, Dodi. 2016. "Perkembangan Visual Poster Pemilu Di Indonesia." Jurnal Dimensi DKV: $\begin{array}{llllll}\text { Seni Rupa Dan } & \text { Desain }\end{array}$ https://trijurnal.lemlit.trisakti.ac.id/seni/article/view/406.

Surya, Roberta Zulfhi, Dwi Yuli Prasetyo, and Ratna Witasari. 2017. "Peningkatan Value Baliho dengan Pendekatan Short Term Memory pada Baliho Calon Bupati Indragiri Hilir Provinsi Riau." Journal of Industrial Engineering and Management Systems 8 (1): 79-90. https://journal.ubm.ac.id/index.php/jiems/article/view/136.

swastika. 2019. "Macam-macam Media Iklan Outdoor." Swastika Advertising. Last Modified 17 Oktober. https://swastikaadvertising.com/macam-macam-media-iklan-outdoor/.

Yuliyanto, Muchamad. 2016. "Evaluasi Alat Peraga Kampanye Pemilihan Umum Di Era Demokrasi Elektoral." Jurnal Ilmu Sosial $13 \quad$ (1): 33-41. https://doi.org/10.14710/jis.13.1.2014.33-41.

Yunanda, Sigit Eka. 2020. "Pandemi Covid-19, Partisipasi Masyarakat Naik Di Pilkada Serentak Riau." Riau Online, $14 \quad$ Desember, 2020. https://www.riauonline.co.id/riau/read/2020/12/14/pandemi-covid-19-partisipasimasyarakat-naik-di-pilkada-serentak-riau. 